\title{
Analisis Faktor-Faktor yang Mempengaruhi Pilihan Jenis Minuman pada Situasi Konsumsi Hang-Out dan Celebration
}

\author{
Zeffry Alamsyah \\ Mahasiswa Program Doktor Manajemen dan Bisnis IPB \\ Region Director PT Coca-Cola Amatil Indonesia \\ Ujang Sumarwan \\ Program Doktor Manajemen dan Bisnis IPB \\ Guru Besar Ilmu Perilaku Konsumen IPB \\ Sumarwan@mma.ipb.ac.id \\ Hartoyo \\ Program Pascasarjana Manajemen \& Bisnis IPB \\ Departemen Ilmu Keluarga \& Konsumen Fakultas Ekologi Manusia IPB \\ Eva Z. Yusuf \\ Program Pascasarjana Manajemen \& Bisnis IPB
}

\begin{abstract}
Soft-drink market in Indonesia continuously grows in the last ten years; however the growth is varied among soft-drink categories in different years. This encourages practitioners in soft-drink industry to understand what factors influencing the consumer when they buy soft-drink to consume, as this will be beneficial to formulate an effective marketing strategy. This research elaborates factors that are predicted as influencer for consumer in choosing soft-drink to buy and consume during hang-out and celebration situation. From 26 factors of product attributes, consumer characteristics, social, and environmental, there are 11 factors which significantly influence respondent decision to choose any type of soft-drink. These are: age, education, household expenditure, hang-out frequency, product availability, taste, aroma, product freshness, manufacturer reputation, and peer's choice of drink. Bottled water, carbonated soft-drink, and ready to drink tea are the most chosen soft-drink categories by respondent.
\end{abstract}

Keywords: Consumption Situation, Influencing Factors, Soft-Drink, Multinomial Logit.

\section{Pendahuluan}

Pasar minuman ringan di Indonesia terus berkembang selama sepuluh tahun terakhir. Konsumen dalam kondisi kebutuhan minum yang sama dapat memilih jenis produk berbeda, sehingga sebenarnya merek-merek minuman ringan bersaing tidak hanya dalam satu jenis minuman ringan saja, tetapi juga dengan merek-merek dari jenis minuman ringan lain, yang sama-sama dapat dipilih untuk memenuhi kondisi kebutuhan minum yang sama. Pemahaman mengenai faktor-faktor yang 
mempengaruhi konsumen dalam memutuskan jenis minuman yang dipilih akan sangat membantu perusahaan menyusun strategi pemasaran yang efektif.

Hasil riset menunjukkan 35\% minuman ringan di Indonesia dikonsumsi untuk aktifitas gaya hidup dan bukan karena haus atau aktifitas makan $\left(\mathrm{CCl}, 2008^{\mathrm{a}}\right)$. Salah satu situasi konsumsi yang berhubungan dengan gaya hidup adalah kondisi kebutuhan minum hang-out dan celebration di mana minuman dikonsumsi sebagai pelengkap dalam kegiatan bersosialisasi, dalam artian sebagai alat untuk memulai komunikasi, mempererat kebersamaan, atau meningkatkan kegembiraan $\left(\mathrm{CCl}, 2008^{\mathrm{a}}\right)$. Pemahaman mengenai faktor-faktor yang menjadi pertimbangan konsumen dalam memilih jenis minuman ringan akan bermanfaat bagi produsen untuk menyusun strategi pemasaran yang lebih efektif, selain memperkaya pustaka mengenai pengambilan keputusan konsumen untuk produk kebutuhan sehari-hari seperti minuman ringan.

Proses pengambilan keputusan generik terdiri dari lima tahap, yaitu pengenalan masalah, pencarian alternatif pemecahan masalah, evaluasi alternatif, pembelian/konsumsi dan evaluasi sesudah pembelian (Peter dan Olson, 2008; Sumarwan, 2004; Blackwell et al., 2001; Mowen, 1993). Menurut Sumarwan (2004), serta Howard dan Seth dalam Farley dan Ring (1970), proses pengambilan keputusan ini dipengaruhi oleh tiga komponen, yaitu perbedaan individu, faktor lingkungan, dan strategi pemasaran.

Konsumen menggunakan berbagai kriteria dalam mengevaluasi alternatif produk yang akan dipilih. Menurut Peter and Olson (2008), konsumen mempertimbangkan konsekuensi fungsional, psikososial, dan finansial; menurut Hawkins et al., (2007), kriteria yang digunakan adalah atribut yang relevan untuk kategori produk; menurut Schiffman dan Kanuk (1991), kriteria pemilihan konsumen adalah atribut produk yang dianggap penting; sedangkan menurut Assael (1992) konsumen akan menggunakan strategi berbasis atribut atau produk, atau tanpa strategi.

Situasi konsumsi merupakan kondisi sementara pada tempat dan waktu yang mempengaruhi pilihan konsumen (Sumarwan, 2004; Assael, 1992), sehingga situasi ketika konsumen membeli dan mengkonsumsi produk ikut menentukan pilihan jenis dan merek.

Menurut Ansary (2006), strategi marketing disusun dalam dua tingkat, yaitu tingkat pertama di mana perusahaan menentukan segmen pasar yang ditargetkan dan tingkat kedua di mana perusahaan menyusun bauran pemasaran untuk memenangkan persaingan di segmen yang dipilih.

Berdasarkan hal tersebut, maka tujuan penelitian ini adalah:

a) Menganalisis perilaku konsumsi berbagai minuman ringan.

b) Mengidentifikasi faktor-faktor yang mempengaruhi konsumen dalam memilih jenis minuman ringan di situasi konsumsi hang-out dan celebration.

c) Memanfaatkan pemahaman mengenai faktor-faktor yang mempengaruhi pilihan konsumen untuk mengembangkan strategi pemasaran yang efektif di situasi konsumsi hang-out dan celebration.

\section{Metode Penelitian}

Konsumen dalam memilih jenis minuman ringan di situasi konsumsi hang-out dan celebration dipengaruhi oleh faktor-faktor atribut produk, karakteristik individu, 
tempat penjualan, gejala penyakit, dan kepemilikan sumber air layak minum. Model penelitian yang digunakan diperlihatkan pada Gambar 1.

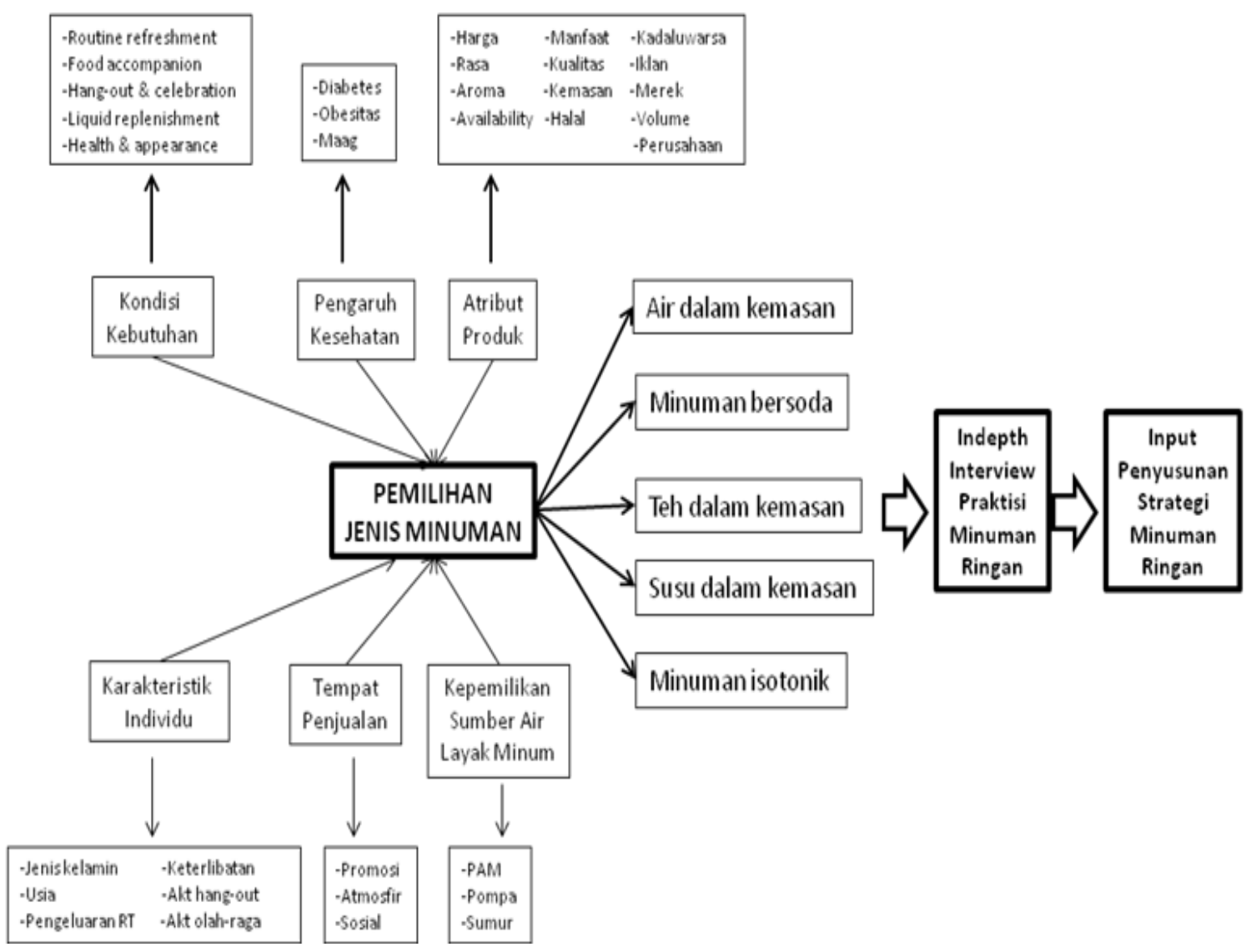

Gambar 1. Model Penelitian

Penelitian ini dilakukan di 5 kotamadya DKI Jakarta pada bulan September 2009. Jumlah responden dihitung dengan menggunakan sampling calculator. Jumlah 400 responden didapatkan dengan memperhitungkan jumlah penduduk di propinsi DKI Jakarta 8,47 juta jiwa, dan di tingkat respons $50 \%$ didasarkan pengalaman penelitian ke rumah tangga sebelumnya, dan dengan tingkat kesalahan $5 \%$.

Responden dipilih secara acak dengan metode multistage random sampling dari tingkat kotamadya sampai dari tingkat rumah tangga. Proporsi jumlah responden di setiap kotamadya sama dengan proporsi jumlah penduduknya. Pengumpulan data dilakukan dengan wawancara menggunakan kuesioner ke responden di rumat tangga yang terpilih.

Analisis faktor yang menjadi pertimbangan konsumen dalam memilih jenis minuman ringan dilakukan dengan model multinomial logit. Model multinomial logit dipilih karena merupakan model logistik dengan lebih dari dua peubah terikat, sehingga memungkinkan untuk digunakan dalam menentukan pilihan di antara lebih dari dua alternatif (Siregar et al., 2006). Selain itu, model regresi logistik dipilih karena memungkinkan penggunaan peubah bebas dengan respons continue (numerikal atau rangking) maupun categorical (nominal atau ordinal) untuk memperkirakan peluang terjadinya suatu hasil. 
Ada lima peubah terikat yang menjadi alternatif pilihan jenis minuman dalam model penelitian ini, yaitu air dalam kemasan, minuman bersoda, teh dalam kemasan, susu dalam kemasan, dan minuman isotonik. Kelima jenis minuman ringan ini sudah mewakili lebih dari 90\% volume pasar minuman ringan di Indonesia (CCBI, 2007ª).

Peubah bebas dari faktor-faktor yang diduga mempengaruhi responden dalam memilih jenis minuman ringan berjumlah 26, yang terdiri dari 9 peubah dengan respons nominal yaitu jenis kelamin, usia, pendidikan terakhir, pengeluaran rumah tangga, kebiasaan olahraga, kebiasaan hang-out, keterlibatan konsumen, pengaruh kesehatan, dan kepemilikan sumber air layak minum, serta 17 peubah dengan respons rangking, yaitu harga, banyaknya toko menjual, rasa, aroma, manfaat yang dirasakan, kemasan yang higienis, mutu yang dipercaya, label halal, tanggal kedaluwarsa, keterkenalan merek, banyaknya isi kemasan, kemenarikan iklan, keterkenalan perusahaan, saran pramuniaga, displai yang mencolok, atmosfer toko yang menyenangkan, dan pilihan minuman teman.

Menurut Siregar et al. (2006), model multinomial logit adalah model logistik yang peubah terikatnya bukan merupakan pilihan yang dikotomi (ya atau tidak), melainkan pilihan berganda yang lebih dari dua. Jika dalam model regresi logistik dikotomi peubah terikat dinyatakan dalam fungsi logit untuk $Y=1$ dibanding dengan fungsi logit untuk $Y=0$, dalam model logistik dengan lima kategori fungsi logit tersebut ada empat. Fungsi logit model multinomial logit penelitian dengan lima peubah terikat yaitu $Y=0$ adalah air dalam kemasan sebagai peubah pembanding, $Y=1$ adalah minuman bersoda, $Y=2$ adalah teh dalam kemasan, $Y=3$ adalah susu dalam kemasan, dan $Y=4$ adalah minuman isotonik, sehingga:

a) Fungsi logit minuman bersoda terhadap air dalam kemasan:

$$
\begin{gathered}
z_{1}(x)=\ln \operatorname{Pr}(Y=1 \mid x)=\beta_{10}+\beta_{11} x_{1}+\beta_{12} x_{2}+\ldots .+\beta_{1 p} x_{2 p} \\
\operatorname{Pr}(Y=0 \mid x)
\end{gathered}
$$

b) Fungsi logit teh dalam kemasan terhadap air dalam kemasan:

$$
\begin{gathered}
z_{2}(x)=\ln \operatorname{Pr}(Y=2 \text { I } x)=\beta_{20}+\beta_{21} x_{1}+\beta_{22} x_{2}+\ldots .+\beta_{2 p} x_{p} \ldots . . \\
\text { Pr }(Y=0 \text { I } x)
\end{gathered}
$$

c) Fungsi logit susu dalam kemasan terhadap air dalam kemasan:

$$
\begin{gathered}
z_{3}(x)=\ln \operatorname{Pr}(Y=3 \mid x)=\beta_{30}+\beta_{31} x_{1}+\beta_{32} x_{2}+\ldots . .+\beta_{3 p} x_{p} \ldots \ldots . \\
\\
\operatorname{Pr}(Y=0 \mid x)
\end{gathered}
$$

d) Fungsi logit minuman isotonik terhadap air dalam kemasan:

$$
\begin{aligned}
Z_{4}(x)=\ln \operatorname{Pr}(Y=4 \mid x)= & \beta_{40}+\beta_{41} x_{1}+\beta_{42} x_{2}+\ldots . .+\beta_{4 p} x_{p} \ldots . . .(4) \\
& \operatorname{Pr}(Y=0 \mid x)
\end{aligned}
$$

Hasil analisis model multinomial logit kemudian digunakan sebagai input indepth interview tentang perkembangan pasar, penerimaan konsumen terhadap jenis minuman ringan, serta peluang dan ancaman terhadap industri. Interview dilakukan dengan satu orang pengambil keputusan di bidang pemasaran dari masing-masing perusahaan dengan pangsa pasar terbesar di kelima jenis minuman ringan yang diteliti. 
Proses interview dilakukan secara terpisah dengan masing-masing pengambil keputusan dengan menggunakan output hasil analisis multinomial logit sebagai panduan pertanyaan. Hasil in-depth interview kemudian diolah sebagai bahan menyusun analisis SWOT (strengths, weaknesses, opportunities, threats) untuk menyusun kerangka strategi pemasaran.

\section{Hasil Penelitian}

\section{III.1. Profil Responden}

Mayoritas responden merupakan kelompok usia muda, di mana kelompok usia 1225 tahun merupakan $46 \%$ dari total responden, kelompok usia 26-35 tahun sebanyak $36 \%$, dan kelompok usia 36-40 tahun sebanyak 18\%. Sebagian besar responden berpendidikan sekolah menengah atau lebih rendah, $15 \%$ responden dengan pendidikan SD dan sederajat, 23\% SMP dan sederajat, 52\% SMU dan sederajat, dan 9\% Diploma atau lebih tinggi.

Dari segi profesi, 23\% adalah pelajar dan mahasiswa, $24 \%$ karyawan dan wiraswasta, $43 \%$ ibu rumah tangga, dan $10 \%$ pengangguran. Proporsi ibu rumah tangga yang separuh dari responden menyebabkan $67 \%$ dari responden adalah wanita, sedangkan pria $33 \%$.

Sebagian besar responden memiliki pengeluaran rumah tangga per bulan di bawah Rp1.750.000 per bulan atau kurang yang berarti ada di kelompok sosial ekonomi C atau lebih rendah. Responden dengan pengeluaran rumah tangga per bulan > Rp2.500.000 merupakan 12\% responden, Rp1.750.000-2.500.000 sebesar 26\%, Rp1.250.000-1.750.000 sebanyak 29\%, dan < Rp1.250.00 sejumlah 33\%.

\section{III.2. Model Multinomial Logit Situasi Konsumsi Hang-Out dan Celebration}

Dari 314 responden yang menjawab pertanyaan tentang pilihan minuman di situasi konsumsi hang-out dan celebration, hanya tiga orang yang memilih susu dalam kemasan, sehingga model multinomial logit untuk situasi konsumsi ini hanya dibuat untuk minuman bersoda, teh dalam kemasan, dan minuman isotonik, dengan air dalam kemasan sebagai peubah pembanding. Dari 26 peubah bebas yang digunakan dalam penyusunan model terdapat 11 peubah yang signifikan untuk masuk ke model situasi konsumsi hang-out dan celebration, di mana empat adalah peubah diukur dengan skala nominal, yaitu usia, pendidikan terakhir, pengeluaran rumah tangga, dan frekuensi hang-out; dan tujuh adalah peubah yang diukur dengan skala rangking yaitu rasa, aroma, tanggal kedaluwarsa, keterkenalan perusahaan pembuat, atmosfer toko, dan pilihan minuman pembeli lain.

Hasil uji khi kuadarat dari model fitting information menunjukan nilai signifikansi $0.000^{* *}$, artinya model final dapat digunakan untuk melakukan analisis. Hasil uji Pearson dan Deviance untuk melihat kecocokan model dengan data yang digunakan (goodness of fit), masing-masing menghasilkan nilai signifikansi 1,000, di mana nilai signifikansi lebih besar dari 0,05 dan mendekati 1 mengindikasikan data dan asumsi yang digunakan sesuai untuk membangun model. Pengukuran pseudo $\mathrm{R}^{2}$ dengan uji Cox \& Snell dan Nagelkerke untuk melihat keragaman peubah terikat yang dapat dijelaskan model nilainya 0,465 dan 0,501 . Nilai ketepatan prediksi model adalah $56,8 \%$. 


\section{III.3. Model Minuman Bersoda}

Sebagian besar pembelian minuman bersoda merupakan keputusan yang tidak direncanakan. Dari $100 \%$ responden, hanya $10 \%$ yang menjawab pembelian minuman bersoda direncanakan terlebih dahulu, sedangkan $42 \%$ tidak direncanakan, dan $48 \%$ direncanakan atau tidak tergantung dari situasi konsumsinya. Pembelian minuman bersoda merupakan keputusan individual. Sebanyak $75 \%$ responden menjawab pembelian minuman bersoda adalah inisiatif sendiri dan hanya $25 \%$ yang menjawab karena pengaruh orang lain.

Minuman bersoda merupakan salah satu minuman ringan yang paling banyak dipilih di situasi konsumsi hang-out dan celebration. Dari 100\% responden, $29 \%$ memilih minuman bersoda, 32\% teh dalam kemasan, 30\% air dalam kemasan, $6 \%$ minuman isotonik, $1 \%$ susu dalam kemasan, dan $1 \%$ minuman lain di luar kelima jenis minuman ringan yang diteliti.

Nilai koefisien fungsi logit model multinomial logit minuman bersoda dengan air dalam kemasan sebagai pembanding dan interpretasinya yang dibaca dari nilai eksponensial $\beta$ dicantumkan pada Tabel 1.

Tabel 1. Koefisien Fungsi Logit Model Minuman Bersoda

\begin{tabular}{|c|c|c|c|}
\hline \multirow[t]{2}{*}{ Peubah bebas } & \multirow[t]{2}{*}{$\alpha$} & \multicolumn{2}{|c|}{$\operatorname{Ln}(\mathrm{p} 1 / \mathrm{p} 0)$} \\
\hline & & $\beta$ & $\operatorname{Exp}(\beta)$ \\
\hline Usia (tahun) & $* *$ & & \\
\hline $12-25$ tahun & & $1,7 * *$ & 5,7 \\
\hline 26-35 tahun & & 0,7 & 2,1 \\
\hline 36-40 tahun & & & \\
\hline Pendidikan terakhir & $*$ & & \\
\hline Tidak sekolah, SD, SMP & & $-0,8$ & 0,4 \\
\hline SMU dan sederajat & & $-0,2$ & 0,8 \\
\hline Diploma, S1, S2, S3 & & & \\
\hline Pengeluaran rumah tangga (Rp 000) & *** & & \\
\hline$<1250$ & & $-0,6$ & 0,5 \\
\hline $1250-1750$ & & $-1,1$ & 0,3 \\
\hline $1750-2500$ & & 0,2 & 1,2 \\
\hline$>3500$ & & & \\
\hline Frekuensi hang-out & *** & & \\
\hline$>4 x$ sebulan $(>1 x /$ minggu $)$ & & 0,7 & 1,9 \\
\hline 4x sebulan $(1 \mathrm{x} / \mathrm{minggu})$ & & $1,6 * *$ & 4,8 \\
\hline$<4 x$ sebulan/tidak pernah & & & \\
\hline Banyaknya toko menjual & ** & $-0,1$ & 0,9 \\
\hline Rasa produk & ** & $-0,3 * *$ & 0,7 \\
\hline Aroma produk & *** & $-0,1$ & 0,9 \\
\hline Tanggal kedaluwarsa & *** & 0 & 1 \\
\hline Keterkenalan perusahaan & $* *$ & 0 & 1 \\
\hline Atmosfer toko & $* *$ & $-0,2 *$ & 0,8 \\
\hline Pilihan teman/pembeli lain & $* *$ & $-0,2 * *$ & 0,8 \\
\hline
\end{tabular}

Faktor usia akan mempengaruhi pilihan jenis minuman ringan, karena dengan bertambahnya usia akan lebih berhati-hati dengan asupan makanan dan minuman ke dalam tubuhnya. Usia responden yang diukur dengan skala nominal merupakan peubah sangat nyata pada tingkat kesalahan $1 \%$. Dari tiga kategori dalam peubah usia, 
yaitu 12-25 tahun, 26-35 tahun, dan 36-40 tahun sebagai kategori pembanding, responden di kelompok usia 12-25 tahun menunjukan kecenderungan lebih besar memilih soda daripada kelompok usia lainnya. Nilai nyata eksponensial $\beta$ dari kategori usia 12-25 tahun pada Tabel 2 adalah 5,7 yang artinya responden di kelompok usia tersebut memiliki peluang lebih besar 5,7 kali untuk memilih soda daripada air dalam kemasan, dibandingkan responden usia 36-40 tahun yang menjadi kategori pembanding. Kecenderungan yang lebih besar dari kelompok usia 12-25 tahun untuk memilih soda menunjukkan usia lebih muda merupakan target potensial untuk pemasaran minuman ringan seperti soda.

Pendidikan terakhir responden mempengaruhi seberapa banyak pengetahuan responden tentang manfaat dan dampak masing-masing jenis minuman ringan, sehingga akan lebih berhati-hati dalam menentukan pilihan. Pendidikan terakhir responden merupakan peubah nyata di model hang-out dan celebration pada tingkat kesalahan 5\%. Tidak ada nilai eksponensial $\beta$ yang nyata di kategori pendidikan terakhir menunjukan meskipun peubah ini nyata sebagai faktor yang menjadi pertimbangan responden, tetapi tidak ada perbedaan peluang untuk memilih minuman bersoda di antara kategori-kategori peubahnya, yaitu antarresponden dengan tingkat pendidikan terakhir yang berbeda.

Pengeluaran rumah tangga sangat nyata pada model hang-out dan celebration pada tingkat kesalahan 1\%. Seperti juga pada peubah sebelumnya, tidak ada nilai eksponensial $\beta$ yang nyata di kategori pengeluaran rumah tangga menunjukan meskipun peubah ini nyata sebagai faktor yang menjadi pertimbangan responden, tetapi tidak ada perbedaan peluang untuk memilih minuman bersoda di antara kategori-kategori peubahnya, yaitu antarresponden dengan tingkat pengeluaran rumah tangga yang berbeda.

Frekuensi hang-out merupakan peubah sangat nyata pada tingkat kesalahan $1 \%$. Nilai signifikan eksponensial $\beta$ dari frekuensi hang-out $1 x$ seminggu untuk fungsi logit soda adalah 4,8 . Interpretasi data ini adalah responden dengan frekuensi hang-out $1 x$ seminggu memiliki peluang lebih besar 4,8 kali untuk memilih soda daripada air; dibandingkan dengan responden dengan frekuensi hang-out kurang dari 1x seminggu yang menjadi kategori pembanding. Tempat hang-out merupakan lokasi di mana responden membiasakan mengonsumsi minuman ringan seperti soda, teh, dan isotonik, sehingga produsen bisa memanfaatkannya sebagai media untuk aktifitas pemasaran.

Konsumen yang bersosialisasi di restoran atau kafe atau warung di mana aktifitas hang-out dan celebration dilakukan akan memesan minuman dari pilihan yang tersedia di tempat tersebut dan tidak akan berpindah tempat karena pilihan minuman yang dicari tidak ada. Hal ini menyebabkan ketersediaan produk di sebanyak mungkin outlet menjadi sangat penting di kondisi kebutuhan hang-out dan celebration. Banyaknya toko yang menjual merupakan peubah sangat nyata pada tingkat kesalahan $1 \%$. Meskipun demikian nilai eksponensial $\beta$ dari peubah banyaknya toko yang menjual tidak signifikan pada fungsi logit soda. Hal ini mengindikasikan meskipun faktor ini menjadi pertimbangan responden dalam memilih, perubahan tingkat kepentingan banyaknya toko yang menjual tidak mempengaruhi peluang responden untuk memilih soda daripada air. 
Rasa minuman merupakan peubah bebas sangat nyata pada tingkat kesalahan $1 \%$. Nilai eksponensial $\beta$ peubah rasa yang diukur dengan skala rangking pada fungsi logit soda besarnya adalah 0,7 . Hal ini berarti responden yang mementingkan rasa berpeluang lebih besar untuk memilih soda daripada air. Setiap kenaikan urutan rangking rasa satu tingkat, misalnya dari tingkat kepentingan nomor 1 menjadi nomor 2 berarti tingkat kepentingannya berkurang, peluang responden untuk memilih minuman bersoda menurun 0,7 kali. Sebaliknya penurunan urutan rangking rasa misalnya dari urutan 2 menjadi urutan 1, berarti tingkat kepentingannya meningkat, peluang responden memilih minuman bersoda meningkat 1,43 kali ( 1 dibagi 0,7$)$. Rasa yang enak merupakan faktor penting dalam pertimbangan responden untuk memilih minuman bersoda.

Aroma juga menjadi faktor yang dipertimbangkan, karena aroma dari minuman yang dipilih akan tercium oleh orang-orang yang bersosialisasi bersama. Aroma adalah peubah bebas sangat nyata pada tingkat kesalahan $1 \%$. Nilai eksponensial $\beta$ peubah bebas aroma tidak nyata pada fungsi logit soda, yang berarti meskipun peubah ini menjadi pertimbangan konsumen dalam memilih, perubahan tingkat kepentingan aroma tidak mempengaruhi peluang responden untuk memilih minuman bersoda.

Lokasi di mana aktifitas sosialisasi dilakukan yang merupakan tempat umum membuat responden merasa perlu memastikan keamanan minuman yang dikonsumsi dari segi higienisnya. Memeriksa tanggal kedaluwarsa produk dan memilih produksi dari perusahaan yang terkenal merupakan salah satu tindakan untuk memastikan keamanan produk. Tanggal kedaluwarsa merupakan peubah sangat nyata pada tingkat kesalahan 1\%. Meskipun demikian, nilai eksponensial $\beta$ peubah bebas tanggal kedaluwarsa tidak nyata pada fungsi logit soda, yang artinya walaupun tanggal kedaluwarsa menjadi salah satu pertimbangan responden dalam memilih, perubahan tingkat kepentingan tanggal kedaluwarsa tidak mempengaruhi peluang responden untuk memilih minuman bersoda.

Penjelasan yang sama juga berlaku untuk peubah bebas keterkenalan perusahaan. Meskipun pada model hang-out dan celebration peubah ini sangat nyata pada tingkat kesalahan $1 \%$, namun pada fungsi logit soda nilai eksponensial $\beta$ tidak nyata. Hal ini menunjukkan perubahan tingkat kepentingan keterkenalan perusahaan tidak mempengaruhi peluang responden untuk memilih minuman bersoda, walaupun keterkenalan perusahaan menjadi salah satu faktor yang dipertimbangkan responden.

Atmosfer toko dipengaruhi oleh faktor fisik seperti bangunan, luas ruangan, perabotan, dan displai produk. Faktor nonfisik seperti suhu ruangan, penerangan, latar belakang musik; dan faktor sosial seperti sikap pramuniaga dan interaksi antarpengunjung toko. Persepsi yang positif terhadap atmosfer toko akan mempengaruhi kondisi emosional konsumen yang akhirnya dapat mempengaruhi keputusan pembelian (Pan et al., 2008). Atmosfer toko merupakan peubah yang sangat nyata pada model hang-out dan celebration pada tingkat kesalahan $1 \%$. Nilai nyata eksponensial $\beta$ peubah atmosfer toko yang diukur dengan skala rangking untuk fungsi logit soda besarnya 0,8 , yang artinya responden yang menganggap penting atmosfer toko memiliki peluang lebih besar untuk memilih soda dibandingkan responden yang tidak menganggap penting atmosfer toko. Setiap kenaikan urutan rangking atmosfer toko satu tingkat, misalnya dari tingkat kepentingan nomor 1 
menjadi nomor 2, berarti tingkat kepentingannya berkurang, maka peluang responden untuk memilih minuman bersoda berkurang 0,8 kali; sebaliknya penurunan urutan rangking atmosfer toko, misalnya dari urutan 2 menjadi urutan 1 , berarti tingkat kepentingannya meningkat, peluang responden memilih minuman bersoda meningkat 1,25 kali (1 dibagi 0,8 ). Produsen minuman ringan dapat memanfaatkan atmosfer toko sebagai bagian dari bauran promosi untuk mendorong pemasaran, misalnya melalui interior ruangan atau interaksi pramuniaga.

Tujuan minum sebagai pelengkap aktifitas bersosialisasi membuat pilihan minuman juga terpengaruh oleh pilihan orang-orang yang bersosialisasi bersama. Pilihan teman merupakan peubah sangat nyata pada tingkat kesalahan $1 \%$. Nilai eksponensial $\beta$ dari peubah bebas pilihan teman yang diukur dengan skala rangking pada fungsi logit soda nilainya 0,8 , artinya responden mementingkan pilihan teman memiliki peluang lebih besar untuk memilih soda daripada air dibandingkan dengan responden yang tidak mementingkan pilihan teman. Setiap kenaikan urutan rangking pilihan teman satu tingkat misalnya dari tingkat kepentingan nomor 1 menjadi nomor 2, berarti tingkat kepentingannya berkurang, maka peluang responden untuk memilih minuman bersoda menurun 0,8 kali; sebaliknya penurunan urutan rangking pilihan teman, misalnya dari urutan 2 menjadi urutan 1, berarti tingkat kepentingannya meningkat, maka peluang responden memilih minuman bersoda meningkat 1,25 kali ( 1 dibagi 0,8). Mengingat pilihan teman merupakan faktor pendorong keputusan untuk memilih minuman ringan, komunikasi pemasaran untuk soda, teh, dan isotonik dapat menonjol di saat kebersamaan bersama teman sebagai tema; di mana minuman menjadi sarana menghangatkan atau memeriahkan kebersamaan.

\section{III.4. Model Teh dalam Kemasan}

Teh dalam kemasan merupakan produk yang sebagian besar dibeli dengan tidak direncanakan terlebih dahulu. Dari $100 \%$ responden hanya $14 \%$ yang menjawab pembelian teh dalam kemasan direncanakan terlebih dahulu, 47\% tidak direncanakan, dan 39\% direncanakan atau tidak tergantung dari situasi konsumsinya.

Seperti pada pembelian minuman bersoda, pembelian teh dalam kemasan merupakan keputusan yang individual. Sebanyak $82 \%$ responden menjawab pembelian teh dalam kemasan adalah inisiatif sendiri dan $18 \%$ karena pengaruh orang lain.

Teh dalam kemasan merupakan jenis minuman ringan yang paling banyak dipilih di situasi konsumsi hang-out dan celebration. Dari 100\% responden, 32\% memilih teh dalam kemasan, 29\% memilih minuman bersoda, 30\% air dalam kemasan, 6\% minuman isotonik, $1 \%$ susu dalam kemasan dan $1 \%$ minuman lain di luar kelima jenis minuman ringan yang diteliti.

Nilai koefisien fungsi logit model multinomial logit teh dalam kemasan dengan air dalam kemasan sebagai pembanding dan interpretasinya yang dibaca dari nilai eksponensial $\beta$ dicantumkan pada Tabel 2. 
Tabel 2. Koefisien Fungsi Logit Model Teh Dalam Kemasan

\begin{tabular}{|c|c|c|c|}
\hline \multirow[t]{2}{*}{ Peubah bebas } & \multirow[t]{2}{*}{$\alpha$} & \multicolumn{2}{|c|}{$\operatorname{Ln}(\mathrm{p} 2 / \mathrm{p} 0)=$ tea } \\
\hline & & $\beta$ & $\operatorname{Exp}(\beta)$ \\
\hline Usia (tahun) & $* *$ & & \\
\hline $12-25$ tahun & & $1,0^{*}$ & 2,8 \\
\hline $26-35$ tahun & & 0,7 & 2,1 \\
\hline \multicolumn{4}{|l|}{ 36-40 tahun } \\
\hline Pendidikan terakhir & $*$ & & \\
\hline Tidak sekolah, SD, SMP & & 0,2 & 1,2 \\
\hline SMU dan sederajat & & 0,6 & 1,8 \\
\hline \multicolumn{4}{|l|}{ Diploma, S1, S2, S3 } \\
\hline Pengeluaran rumah tangga (Rp 000) & ** & & \\
\hline$<1250$ & & 0,5 & 1,6 \\
\hline $1250-1750$ & & $-0,4$ & 0,6 \\
\hline $1750-2500$ & & 0,8 & 2,2 \\
\hline \multicolumn{4}{|l|}{$>3500$} \\
\hline Frekuensi hang-out & ** & & \\
\hline$>4 \mathrm{x}$ sebulan $(>1 \mathrm{x} /$ minggu $)$ & & 0,8 & 2,2 \\
\hline $4 \mathrm{x}$ sebulan $(1 \mathrm{x} / \mathrm{minggu})$ & & $1,7 * *$ & 5,5 \\
\hline \multicolumn{4}{|l|}{$<4 \mathrm{x}$ sebulan/tidak pernah } \\
\hline Banyaknya toko menjual & $* *$ & $-0,1 *$ & 0,9 \\
\hline Rasa produk & ** & $-0,3 * *$ & 0,8 \\
\hline Aroma produk & $* *$ & $-0,2 * *$ & 0,8 \\
\hline Tanggal kedaluwarsa & $* *$ & 0,1 & 1,1 \\
\hline Keterkenalan perusahaan & $* *$ & $-0,1$ & 0,9 \\
\hline Atmosfer toko & $* *$ & $-0,1$ & 0,9 \\
\hline Pilihan teman/pembeli lain & $* *$ & $-0,2 * *$ & 0,8 \\
\hline
\end{tabular}

Usia responden yang diukur dengan skala nominal merupakan peubah sangat nyata pada tingkat kesalahan 1\%. Dari tiga kategori dalam peubah usia, yaitu 12-25 tahun, 26-35 tahun, dan 36-40 tahun sebagai kategori pembanding, responden di kelompok usia 12-25 tahun menunjukan kecenderungan memilih teh dalam kemasan lebih besar daripada kelompok usia lainnya. Nilai nyata eksponensial $\beta$ dari kategori usia 12-25 tahun pada Tabel 3 adalah 2,8 yang artinya responden di kelompok usia 12-25 tahun memiliki peluang lebih besar 2,8 kali memilih teh dalam kemasan daripada air dalam kemasan, dibandingkan responden usia 36-40 tahun yang menjadi kategori pembanding. Kecenderungan kelompok usia 12-25 tahun untuk memilih teh menunjukkan usia yang lebih muda merupakan target potensial untuk pemasaran minuman ringan, termasuk teh dalam kemasan.

Pendidikan terakhir responden merupakan peubah nyata di model hang-out dan celebration pada tingkat kesalahan $5 \%$. Tidak ada nilai eksponensial $\beta$ yang nyata di kategori pendidikan terakhir menunjukan bahwa meskipun peubah ini signifikan sebagai faktor yang menjadi pertimbangan responden, tetapi tidak ada perbedaan peluang untuk memilih teh dalam kemasan di antara kategori-kategori peubahnya, yaitu responden dengan tingkat pendidikan terakhir yang berbeda. 
Pengeluaran rumah tangga sangat nyata pada model hang-out dan celebration pada tingkat kesalahan $1 \%$. Tidak ada perbedaan tingkat nyata kepentingan peubah ini antarkategori pengeluaran rumah tangga seperti yang ditunjukkan dari tidak ada nilai eksponensial $\beta$ yang nyata, yang berarti meskipun peubah ini merupakan faktor yang menjadi pertimbangan responden dalam memilih, tetapi tidak ada perbedaan peluang untuk memilih teh dalam kemasan di antara kategori-kategori peubahnya yaitu antar responden dengan pengeluaran rumah tangga yang berbeda.

Frekuensi hang-out merupakan peubah sangat nyata pada tingkat kesalahan $1 \%$. Nilai nyata eksponensial $\beta$ dari frekuensi hang-out $1 x$ seminggu untuk fungsi logit teh dalam kemasan nilainya 5,5, yang artinya responden dengan frekuensi hang-out $1 x$ seminggu memiliki peluang lebih besar 5,5 kali untuk memilih teh dalam kemasan daripada air; dibandingkan dengan responden dengan frekuensi hang-out kurang dari $1 x$ seminggu yang menjadi kategori pembanding. Hal ini menunjukan tempat hang-out merupakan lokasi yang dimanfaatkan oleh produsen untuk aktifitas marketing minuman ringan teh dalam kemasan.

Banyaknya toko yang menjual merupakan peubah sangat nyata pada tingkat kesalahan $1 \%$. Nilai eksponensial $\beta$ peubah banyaknya toko yang menjual yang diukur dengan skala rangking pada fungsi logit teh dalam kemasan besarnya 0,9, berarti responden mementingkan banyaknya toko yang menjual berpeluang lebih besar untuk memilih teh dalam kemasan daripada air. Setiap kenaikan urutan rangking banyaknya toko menjual satu tingkat, misalnya dari tingkat kepentingan nomor 1 menjadi nomor 2 , berarti tingkat kepentingannya berkurang, peluang responden untuk memilih teh dalam kemasan berkurang 0,9 kali; sebaliknya penurunan urutan rangking banyaknya toko menjual misalnya dari urutan 2 menjadi urutan 1 yang berarti tingkat kepentingannya meningkat, peluang responden memilih teh dalam kemasan bertambah besar 1,11 kali (1:0,9). Responden tidak akan berpindah tempat hang-out karena minuman ringan yang dicari tidak ada, sehingga sangat penting teh dalam kemasan ada di sebanyak mungkin tempat hang-out.

Rasa merupakan peubah sangat nyata pada tingkat kesalahan $1 \%$. Nilai eksponensial $\beta$ peubah rasa yang diukur dengan skala rangking pada fungsi logit banyaknya toko yang menjual besarnya adalah 0,8 , berarti responden mementingkan rasa berpeluang lebih besar untuk memilih teh dalam kemasan daripada air. Setiap kenaikan urutan rangking rasa satu tingkat misalnya dari tingkat kepentingan nomor 1 menjadi nomor 2, berarti tingkat kepentingannya berkurang, maka peluang responden umemilih teh dalam kemasan berkurang 0,8 kali; sebaliknya penurunan urutan rangking rasa, misalnya dari urutan 2 menjadi urutan 1 berarti tingkat kepentingannya meningkat, peluang responden memilih teh dalam kemasan bertambah besar 1,25 kali $(1: 0,8)$. Rasa teh dalam kemasan yang enak menjadi prasyarat responden dalam memilih teh dalam kemasan.

Nilai eksponensial $\beta$ peubah bebas aroma yang diukur dengan skala rangking pada fungsi logit banyaknya toko yang menjual besarnya 0,8 , berarti responden yang mementingkan aroma berpeluang lebih besar untuk memilih teh dalam kemasan daripada air. Setiap kenaikan urutan rangking aroma satu tingkat, misalnya dari tingkat kepentingan nomor 1 menjadi nomor 2, berarti tingkat kepentingannya berkurang, maka peluang responden untuk memilih teh dalam kemasan berkurang 0,8 
kali; sebaliknya penurunan urutan rangking aroma, misalnya dari urutan 2 menjadi urutan 1 , berarti tingkat kepentingannya meningkat, maka peluang responden memilih teh dalam kemasan bertambah besar 1,25 kali $(1: 0,8)$. Selain rasa, aroma teh dalam kemasan juga menjadi prasyarat responden dalam memilih teh dalam kemasan.

Tanggal kedaluwarsa merupakan peubah sangat nyata pada tingkat kesalahan $1 \%$. Meskipun demikian nilai eksponensial $\beta$ peubah bebas tanggal kedaluwarsa tidak nyata pada fungsi logit teh dalam kemasan, artinya walaupun tanggal kedaluwarsa menjadi pertimbangan responden tetapi perubahan tingkat kepentingan tanggal kedaluwarsa tidak mempengaruhi peluang responden untuk memilih teh dalam kemasan.

Penjelasan yang sama juga berlaku untuk peubah bebas keterkenalan perusahaan. Meskipun merupakan peubah ini sangat nyata pada tingkat kesalahan $1 \%$ pada model hang-out dan celebration, nilai eksponensial $\beta$ peubah bebas keterkenalan perusahaan tidak nyata pada fungsi logit teh dalam kemasan, yang artinya perubahan tingkat kepentingan keterkenalan perusahaan tidak mempengaruhi peluang responden untuk memilih teh dalam kemasan, walaupun keterkenalan perusahaan merupakan salah satu faktor pertimbangan responden.

Atmosfer toko merupakan peubah sangat nyata pada tingkat kesalahan $1 \%$. Berbeda denga model minuman bersoda, nilai eksponensial $\beta$ peubah bebas atmosfer toko tidak nyata pada fungsi logit teh dalam kemasan, yang artinya perubahan tingkat kepentingan atmosfer toko tidak mempengaruhi peluang responden untuk memilih teh dalam kemasan, meskipun atmosfer toko menjadi salah satu faktor yang menjadi pertimbangan responden dalam memilih.

Nilai eksponensial $\beta$ peubah bebas pilihan teman yang diukur dengan skala rangking pada fungsi logit teh dalam kemasan nilainya 0,8 , artinya responden mementingkan pilihan teman memiliki peluang lebih besar untuk memilih teh dalam kemasan daripada air dibandingkan dengan responden yang tidak mementingkan pilihan teman. Setiap kenaikan urutan rangking pilihan teman satu tingkat, misalnya dari tingkat kepentingan nomor 1 menjadi nomor 2, berarti tingkat kepentingannya berkurang, maka peluang responden untuk memilih teh dalam kemasan berkurang 0,8 kali; sebaliknya penurunan urutan rangking pilihan teman misalnya dari urutan 2 menjadi urutan 1, berarti tingkat kepentingannya meningkat, maka peluang responden memilih teh dalam kemasan bertambah besar 1,25 kali $(1: 0,8)$. Kepentingan pilihan teman dalam pertimbangan memilih teh dalam kemasan mengindikasikan tema kebersamaan dapat efektif dalam mengkomunikasikan pesan mengenai teh dalam kemasan.

\section{III.5. Model Minuman Isotonik}

Minuman isotonik merupakan produk yang sebagian besar dibeli dengan tidak direncanakan terlebih dahulu, meskipun jumlah yang membeli tanpa perencanaan relatif lebih sedikit dari minuman bersoda dan teh dalam kemasan. Dari $100 \%$ responden, hanya $19 \%$ yang menjawab pembelian minuman isotonik direncanakan terlebih dahulu, sedangkan 31\% tidak direncanakan dan 50\% direncanakan atau tidak tergantung dari situasi konsumsinya. Keputusan pembelian minuman isotonik merupakan keputusan individual. Sebanyak $81 \%$ responden menjawab pembelian minuman isotonik adalah inisiatif sendiri dan $19 \%$ karena pengaruh orang lain. 
Minuman isotonik relatif tidak banyak dipilih di situasi konsumsi hang-out dan celebration. Dari $100 \%$ responden, hanya $4 \%$ yang memilih isotonik, $25 \%$ memilih teh dalam kemasan, $23 \%$ memilih minuman bersoda, 24\% air dalam kemasan, dan $1 \%$ minuman lain di luar kelima jenis minuman ringan yang diteliti. Hal ini dimengerti, karena konsumsi minuman isotonik lebih terbatas pada kegiatan hang-out dan celebration yang berhubungan dengan aktifitas sesudah berolahraga.

Nilai koefisien fungsi logit model multinomial minuman isotonik dengan air dalam kemasan sebagai pembanding dan interpretasinya yang dibaca dari nilai eksponensial $\beta$ dicantumkan pada Tabel 3.

Tabel 3. Koefisien Fungsi Logit Model Isotonik

\begin{tabular}{|c|c|c|c|}
\hline \multirow[t]{2}{*}{ Peubah bebas } & \multirow[t]{2}{*}{$\alpha$} & \multicolumn{2}{|c|}{$\mathrm{Ln}(\mathrm{p} 4 / \mathrm{p} 0)=$ isotonik } \\
\hline & & $\beta$ & $\operatorname{Exp}(\beta)$ \\
\hline Usia (tahun) & $* *$ & & \\
\hline 12-25 tahun & & $1,9 *$ & 6,5 \\
\hline 26-35 tahun & & 1,1 & 3,1 \\
\hline \multicolumn{4}{|l|}{$36-40$ tahun } \\
\hline Pendidikan terakhir & $*$ & & \\
\hline Tidak sekolah, SD, SMP & & $-0,4$ & 0,7 \\
\hline SMU dan sederajat & & $-0,3$ & 0,7 \\
\hline \multicolumn{4}{|l|}{ Diploma, S1, S2, S3 } \\
\hline Pengeluaran rumah tangga $(\mathrm{Rp} 000)$ & $* *$ & & \\
\hline$<1250$ & & 0,6 & 1,8 \\
\hline $1250-1750$ & & $-1,1$ & 0,3 \\
\hline $1750-2500$ & & 1,4 & 4,1 \\
\hline \multicolumn{4}{|l|}{$>3500$} \\
\hline Frekuensi hang-out & $* *$ & & \\
\hline$>4 \mathrm{x}$ sebulan $(>1 \mathrm{x} /$ minggu $)$ & & 0 & 1 \\
\hline 4x sebulan $(1 \mathrm{x} / \mathrm{minggu})$ & & $1,7 * *$ & 5,2 \\
\hline \multicolumn{4}{|l|}{$<4 \mathrm{x}$ sebulan/tidak pernah } \\
\hline Banyaknya toko menjual & $* *$ & $-0,2 *$ & 0,8 \\
\hline Rasa produk & $* *$ & $-0,2 *$ & 0,8 \\
\hline Aroma produk & $* *$ & $-0,1$ & 0,9 \\
\hline Tanggal kedaluwarsa & $* *$ & $-0,1$ & 0,9 \\
\hline Keterkenalan perusahaan & $* *$ & 0 & 1 \\
\hline Atmosfer toko & $* *$ & 0 & 1 \\
\hline Pilihan teman/pembeli lain & $* *$ & $-0,3 * *$ & 0,8 \\
\hline
\end{tabular}

Usia responden diukur dengan skala nominal merupakan peubah sangat nyata pada tingkat kesalahan 1\%. Dari tiga kategori dalam peubah usia, yaitu 12-25 tahun, 26-35 tahun, dan 36-40 tahun sebagai kategori pembanding; responden di kelompok usia 1225 tahun menunjukan kecenderungan lebih besar untuk memilih isotonik daripada kelompok usia lainnya. Nilai nyata eksponensial $\beta$ dari kategori usia 12-25 tahun pada Tabel 3 adalah 6,5 yang artinya responden di kelompok usia 12-25 tahun memiliki peluang lebih besar 6,5 kali untuk memilih isotonik daripada air dalam kemasan, dibandingkan dibandingkan responden usia 36-40 tahun yang menjadi kategori pembanding. Kecenderungan kelompok usia 12-25 tahun untuk memilih isotonik 
menunjukkan usia yang lebih muda merupakan target potensial untuk pemasaran minuman ringan termasuk juga isotonik.

Pendidikan terakhir responden merupakan peubah nyata di model hang-out dan celebration pada tingkat kesalahan $5 \%$. Tidak ada nilai eksponensial $\beta$ yang nyata di kategori pendidikan terakhir menunjukan meskipun peubah ini merupakan pertimbangan responden dalam memilih, tetapi tidak ada perbedaan peluang untuk memilih isotonik di antara kategori-kategori peubahnya, yaitu responden dengan tingkat pendidikan terakhir berbeda.

Pengeluaran rumah tangga sangat nyata pada model hang-out dan celebration pada tingkat kesalahan $1 \%$. Tidak ada nilai eksponensial $\beta$ yang nyata di kategori pengeluaran rumah tangga, meskipun peubah ini menjadi pertimbangan responden dalam memilih isotonik, artinya tidak ada perbedaan peluang untuk memilih isotonik daripada air dalam kemasan di antara kategori-kategori peubahnya, yaitu responden dengan tingkat pengeluaran rumah tangga berbeda.

Frekuensi hang-out merupakan peubah sangat nyata pada tingkat kesalahan $1 \%$. Nilai nyata eksponensial $\beta$ dari frekuensi hang-out $1 x$ seminggu untuk fungsi logit isotonik nilainya 5,2, artinya responden dengan frekuensi hang-out $1 x$ seminggu memiliki peluang lebih besar 5,2 kali untuk memilih isotonik daripada air; dibandingkan dengan responden dengan frekuensi hang-out kurang dari 1x seminggu yang menjadi kategori pembanding. Hal ini menunjukan tempat hang-out merupakan lokasi yang dapat dimanfaatkan oleh produsen untuk aktifitas marketing minuman ringan termasuk isotonik.

Banyaknya toko yang menjual merupakan peubah sangat nyata pada tingkat kesalahan $1 \%$. Nilai eksponensial $\beta$ peubah banyaknya toko yang menjual yang diukur dengan skala rangking pada fungsi logit isotonik besarnya adalah 0,8 , berarti responden mementingkan banyaknya toko yang menjual berpeluang lebih besar untuk memilih isotonik daripada air. Setiap kenaikan urutan rangking banyaknya toko menjual satu tingkat misalnya dari tingkat kepentingan nomor 1 menjadi nomor 2, berarti tingkat kepentingannya berkurang, maka peluang responden untuk memilih isotonik berkurang 0,8 kali; sebaliknya penurunan urutan rangking banyaknya toko menjual, misalnya dari urutan 2 menjadi urutan 1 yang berarti tingkat kepentingannya meningkat, peluang responden memilih isotonik bertambah besar 1,25 kali $(1: 0,8)$. Responden tidak akan berpindah tempat hang-out karena minuman ringan yang dicari tidak ada, sehingga minuman isotonik harus terdistribusi di sebanyak mungkin tempat hang-out.

Rasa merupakan peubah sangat nyata pada tingkat kesalahan $1 \%$. Nilai eksponensial $\beta$ rasa yang diukur dengan skala rangking pada fungsi logit isotonik besarnya 0,8 , yang berarti responden yang mementingkan rasa berpeluang lebih besar untuk memilih isotonik daripada air. Setiap kenaikan urutan rangking rasa satu tingkat, misalnya dari tingkat kepentingan nomor 1 menjadi nomor 2 , berarti tingkat kepentingannya berkurang, peluang responden untuk memilih isotonik berkurang 0,8 kali; sebaliknya penurunan urutan rangking banyaknya toko menjual misalnya dari urutan 2 menjadi urutan 1, berarti tingkat kepentingannya meningkat, maka peluang responden memilih teh dalam kemasan bertambah besar 1,25 kali $(1: 0,8)$. 
Aroma adalah peubah bebas sangat nyata pada tingkat kesalahan $1 \%$. Nilai eksponensial $\beta$ dari peubah bebas aroma tidak nyata pada fungsi logit isotonik, yang berarti meskipun merupakan peubah ini menjadi pertimbangan konsumen dalam memilih, perubahan tingkat kepentingan aroma tidak mempengaruhi peluang responden untuk memilih isotonik.

Tanggal kedaluwarsa merupakan peubah sangat nyata pada tingkat kesalahan $1 \%$. Meskipun demikian, nilai eksponensial $\beta$ peubah bebas tanggal kedaluwarsa tidak signifikan pada fungsi logit isotonik, artinya perubahan tingkat kepentingan tanggal kedaluwarsa tidak mempengaruhi peluang responden untuk memilih isotonik, walaupun peubah ini menjadi pertimbangan responden dalam memilih.

Penjelasan yang sama juga berlaku untuk peubah bebas keterkenalan perusahaan. Meskipun merupakan peubah ini signifikan pada tingkat kesalahan $1 \%$ pada model hang-out dan celebration, nilai eksponensial $\beta$ peubah bebas keterkenalan perusahaan tidak nyata pada fungsi logit isotonik, artinya perubahan tingkat kepentingan keterkenalan perusahaan tidak mempengaruhi peluang responden untuk memilih isotonik, walaupun peubah keterkenalan perusahaan merupakan salah satu faktor yang dipertimbangkan responden dalam memilih.

Atmosfer toko merupakan peubah nyata pada model hang-out dan celebration pada tingkat kesalahan $1 \%$. Meskipun demikian nilai eksponensial $\beta$ peubah bebas atmosfer toko tidak signifikan pada fungsi logit isotonik, artinya perubahan tingkat kepentingan atmosfer toko tidak mempengaruhi peluang responden untuk memilih isotonik, meskipun atmosfer toko menjadi salah satu pertimbangan responden dalam memilih.

Pilihan teman merupakan peubah sangat nyata pada tingkat kesalahan $1 \%$. Nilai eksponensial $\beta$ dari peubah bebas pilihan teman yang diukur dengan skala rangking pada fungsi logit isotonik nilainya 0,8 , artinya responden yang mementingkan pilihan teman memiliki peluang lebih besar untuk memilih isotonik daripada air dibandingkan dengan responden yang tidak mementingkan pilihan teman. Setiap kenaikan urutan rangking pilihan teman satu tingkat, misalnya dari tingkat kepentingan nomor 1 menjadi nomor 2 yang berarti tingkat kepentingannya berkurang, maka peluang responden untuk memilih isotonik berkurang 0,8 kali; sebaliknya penurunan urutan rangking pilihan teman misalnya dari urutan 2 menjadi urutan 1 , berarti tingkat kepentingannya meningkat, maka peluang responden memilih isotonik bertambah besar 1,25 kali $(1: 0,8)$. Mengingat pilihan teman merupakan faktor pendorong keputusan untuk memilih minuman ringan, komunikasi pemasaran isotonik dapat menonjolkan saat kebersamaan bersama teman sebagai tema.

\section{Kesimpulan}

Keputusan pemilihan minuman ringan sebagian besar dilakukan tanpa perencanaan terlebih dahulu, yaitu dilakukan secara individual dengan sedikit pengaruh dari orang lain dan jenis minuman yang paling banyak dikonsumsi dalam situasi konsumsi hangout dan celebration adalah air dalam kemasan, minuman bersoda dan teh dalam kemasan.

Selain faktor-faktor yang merupakan atribut produk, karakteristik individu, dan tempat penjualan, aktifitas bersosialisasi mempengaruhi keputusan pemilihan 
minuman ringan di situasi konsumsi hang-out dan celebration. Rasa minuman, aroma minuman, kemudahan memperoleh produk di banyak toko, keberadaan tanggal kedaluwarsa dan keterkenalan perusahaan pembuat minuman merupakan faktorfaktor yang berasal dari atribut produk dalam memilih minuman ringan. Usia responden, pengeluaran rumah tangga, pendidikan terakhir responden, dan frekuensi hang-out adalah faktor-faktor yang berasal dari karakteristik individu. Atmosfer toko merupakan faktor tempat penjualan dan pilihan pembeli lain pengaruh dari teman bersosialisasi.

Peubah-peubah yang nyata dalam model multinomial logit, hasil analisis SWOT dan pemahaman kondisi empiris penggunaan minuman ringan digunakan untuk menyusun strategi marketing tingkat pertama dalam memilih target segmen dan positioning sedangkan kategori-kategori peubah yang nyata pada model multinomial logit minuman bersoda dan teh dalam kemasan digunakan untuk menyusun strategi marketing tingkat kedua (bauran pemasaran).

\section{Daftar Pustaka}

Assael, H. 1992. Consumer Behavior dan Marketing Action. PWS-KENT Publishing Company, Boston.

Blackwell, RD, P.W Miniard, and J.F Engel. 2001. Consumer Behaviour. Harcourt College Publishers, Forth Worth.

El-Ansary, Al. 2006. Marketing strategy: taxonomy and frameworks. European Business Review, 18(4): 266-293.

Farley, J.U, and L.W Ring. 1970. An empirical test of the Howard-Seth model of buyer behavior. Journal of Marketing Research, 7(4): 427-438.

Hawkins, D.I, D.L Mothersbaugh, and R.J Best. 1989. Consumer Behavior: Building Marketing Strategy. McGraw-Hill/Irwin, New York.

Mowen, J.C. 1993. Consumer Behavior. Macmillan Publishing Company, New York.

Pan, F.C, S.J Su, and C.C Chiang. 2008. Dual attractiveness of winery: atmospheric cues on purchasing. International Journal of Wine, 20(2): 95-110.

Peter, J.P and J.C Olson. 2008. Consumer Behavior and Marketing Strategy. McGrawHill Education (Asia), Boston.

Schiffman, L.G and L.L Kanuk. 1991. Consumer Behavior. Prentice-Hall, Inc, New Jersey.

Siregar, H, Marimin, B. Juanda B, dan NA Achsani. 2006. Metode Kuantitatif untuk Manajemen Bisnis Lanjut. Bahan Perkuliahan Doktor Manajemen Bisnis. Program Pasca Sarjana Manajemen dan Bisnis, Institut Pertanian Bogor, Bogor.

Sumarwan, U. 2004. Perilaku Konsumen: Teori dan Penerapannya dalam Pemasaran. PT Ghalia Indonesia, Bogor. 